\title{
剧立百周年を迎えて
}

\section{松谷 有希雄*}

国立療養所多磨全生園園長

〔受付・掲載決定：2009 年 11 月 30 日]

多磨全生園は、明治 40 年法律第 11 号及びそれ を受けた明治 42 年内務省令第 20 号に基づき、第 一区府県立全生病院（ぜんせいびょういん）とし て設置され、1909 年（明治 42 年） 9 月 28 日に 開院式が挙行されました。その後、1941 年（昭和 16 年） 7 月 1 日に国に移管され、厚生省所管の国 立療養所多磨全生園（たまぜんしょうえん）となっ て今日に至り、同じく 1909 年に発足した他の 4 園とともに、昨年創立百周年を迎えました。

開院式が行われたのと同じ 9 月 28 日には、園内 で創立百周年記念式典を催し、黙䘠の後、園長及 び入所者自治会長の式辞、厚生労働大臣告示、そ してご来賓の都知事（代理）及び東村山市長から ご挨拶を賜り、次いで市内の小中学生から募集し た作文の優秀作品の表彰と発表が行われました。 続いて、式典第二部として日本財団会長の笹川陽 平氏及び国立ハンセン病資料館名誉館長の大谷藤 郎氏から特別講演を頂きました。お二人のお話し は、国際協力及び国内の課題と展望について、そ れぞれの御経験を踏まえた感銘深いもので、療養 所の百年の機会にふさわしい内容でした。

百年の歩みは、平均寿命が 80 歳前後の我々に とって個人の経験を超える長い期間ですが、人類 とハンセン病の有史以来の関わりの中では本当に 短い時間と言えましょう。しかし、この短い時間 にハンセン病の近代史が凝縮されています。

学会の先生方には釈迦に説法ですが、医学的に

*Corresponding author:

国立療養所多磨全生園

干 189-8550 東村山市青葉町 4-1-1

TEL : 042-395-1101 FAX : 042-394-2410

E-mail : matutani@tamazensho.hosp.go.jp
は、二つの大きなことがありました。一つは、ノ ルウェーのゲルハール・ヘンリック・アルマウエル・ ハンセン $(1841$ - 1912) によるらい菌の発見で、 わが国の公立療養所開設に先立つこと 36 年前の 1873 年 (明治 6 年) のことです。らい菌と同じ抗 酸菌に属する結核菌をローベルト・コッホ（1843 - 1910）が発見したのは 1882 年（明治 15 年） ですから、それより早い発見でした。19 世紀の目 覚ましい細菌学興隆の中での出来事です。これに よって、ハンセン病は感染症であるらしいことが 分かり、人類は科学的な対応の手がかりを得たわ けですが、この発見は、当初なかなか人々に受け 入れられませんでした。しかし、コッホなどの努 力により、24 年後の 1897 年（明治 30 年）にべ ルリンで開催された第一回国際らい会議で、ハン セン病の病原体として世界の学者に支持されるよ うになったのはご存じの通りです。公立療養所の 開かれる 12 年前のことです。

二つ目は、第二次大戦中の 1943 年（昭和 18 年） に米国ルイジアナ州カーヴィル療養所の院長ジー・ $\mathrm{H}$ ・ファジェーによって報告された、同所におけ るプロミンの治験での画期的な効果です（いわゆ る「カーヴィルの奇跡」)。菌の発見から 70 年経つ ていました。国内でも、早くも終戦後の 1946 年(昭 和 21 年）には、東京大学医学部薬学科の石館守三 教授がプロミンの合成に成功し、翌 1947 年（昭 和 22 年）からは当園での治験が始まっています。 当時の日本らい学会では同年から毎年プロミンの 効果が発表され、入所者の運動も効を奏し、1949 年（昭和 24 年）には予算化されました。開所か ら 40 年後のことです。同じ頃（1944 年）ワクス マンが結核に有効な抗生物質ストレプトマイシン 
を発見しています。プロミンはサルファ剤の一つ ですが、この発見は、エールリッヒと秦佐八郎に よる駆梅剂サルバルサン等の創製（1910 年）に始 まり、ドーマクによる初のサルファ剂プロントジ ルの開発（1935 年)、さらにフレミングによる最 初の抗生物質ペニシリンの発見（1928 年）及びフ ローリーらによるその再発見（1941 年）へと続く 20 世紀の抗菌薬による化学療法の目覚ましい発展 に連なる出来事です。御承知のとおりハンセン病 の治療は、その後、プロミンをもとに経口薬のダ プソン（DDS）が導入され、更に、殺菌的に作用し、 結核にも有効な抗生物質のリファンピシン、らい 反応にも有効とされるクロファジミン（B663）な どが加わる一方、耐性菌も出現し、現在の多剤併 用療法（MDT）に到達します。WHO の MDT 指針 （1981 年〜）をもとに、日本ハンセン病学会は委 員会を組織し治療指針（2000 年〜）をまとめてい ます。

これら二つの大きな医学上の出来事に呼応して、 社会の動きも大きく二つに分けられます。まず、 ハンセン病が感染症であることが確認されたこと に対応し、それまでは、僅かに、主に外国の宗教 家によって設けられた施設が活動しているだけの
ところに、日露戦争後の 1907 年（明治 40 年）に 患者の隔離を主な内容とする最初の法律が制定さ れ、これに基づいて、 2 年後の 1909 年 (明治 42 年) に冒頭に述べたように当園を含む 5 つの公立の八 ンセン病療養所が開設されました。既に制定され ていたコレラや痘瘡などの急性感染症に対する伝 染病予防法や、その後の結核予防法などと異なり、 原則的に患者の終生にわたる隔離収容が行われた のには、人目につきやすい部位に外見の変化をき たしやすいハンセン病に対する強い偏見、差別が その背景にあったことは疑いありません。制定当 初は、家を離れ放浪を余儀なくされていた人々を 対象にしていましたが、満州事変の始まる 1931 年（昭和 6 年）には法律が改正され、国際的な動 向とは反対に、全ての患者を対象とする絶対隔離 が徹底されていきました。ちなみに、その前年の 1930 年（昭和 5 年）には、最初の国立のハンセ ン病療養所である長島愛生園が開所していますし、 その 10 年後、開戦間近の 1941 年（昭和 16 年） には、当園を含む 5 つの公立療養所が国立に移管 しています。1927 年 (昭和 2 年) の日本癩学会創 設も、一面ではこの文脈の中の出来事として読み 取れます。そして、この考え方は、戦後の1953年(昭

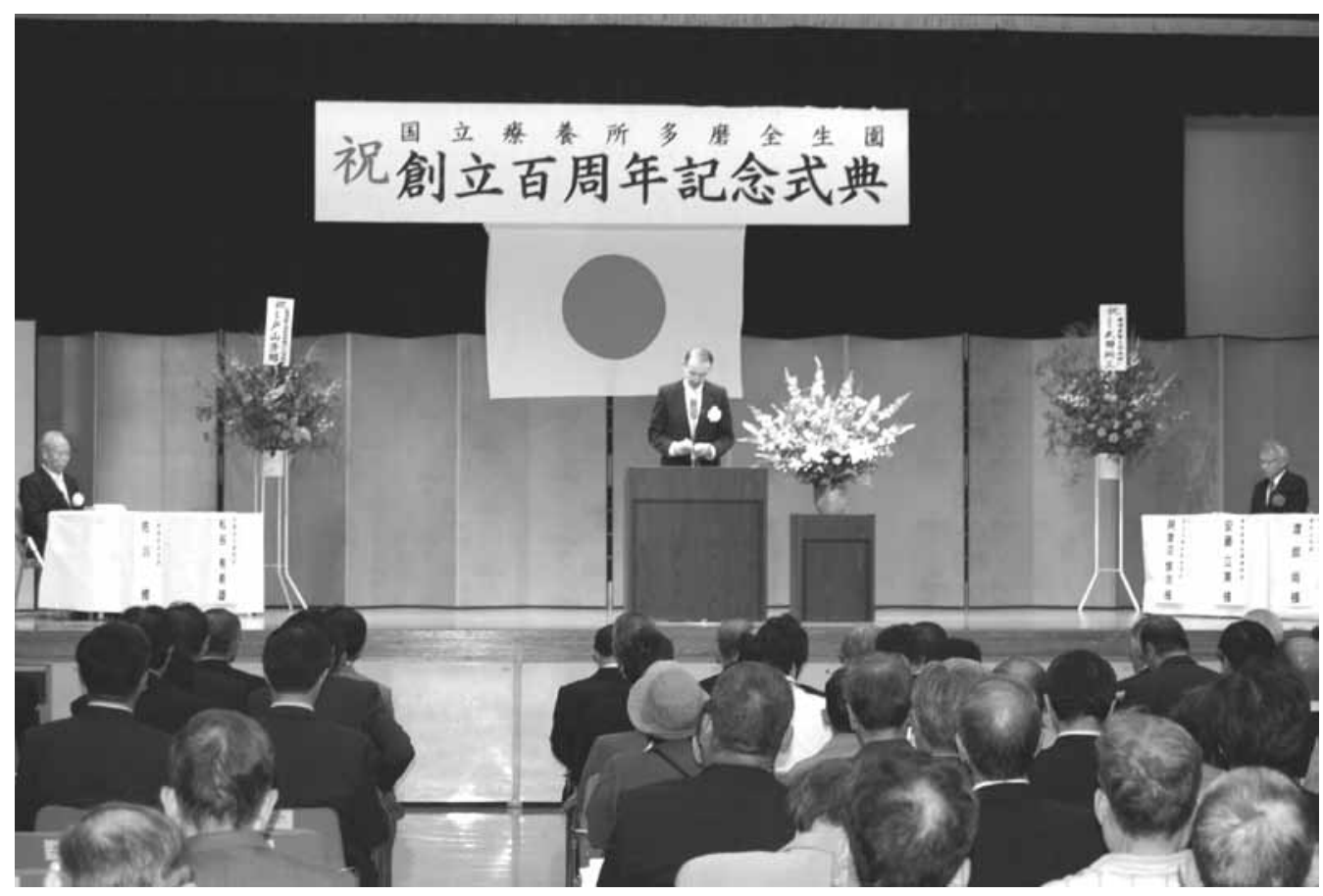


和 28 年）に入所者の組織的な反対にもかかわらず 成立した「らい予防法」へ受け継がれました。

戦後、化学療法の出現によってハンセン病が可 治となったことに対応して、外出などが緩和され、 社会復帰する人も出始女、「らい予防法」は次第に 形骸化していきましたが、世界の趨勢からも乘離 して、隔離を基本とする法そのものは残されたま までした。入所者を始めとする多くの人々の努力 によりそれが廃止され、「らい予防法の廃止に関す る法律」が公布、施行されたのは、今から 14 年前 の 1996 年（平成 8 年）のことです。この間、日 本らい学会は 1995 年 4 月 22 日の総会で、それま での反省とともにらい予防法廃止の見解を表明し ています。らい予防法の廃止は石館による国内で のプロミン合成成功から 50 年後のことで、この遅 れは悔いを千載に残す痛恨事です。その後、国家 賠償請求訴訟が起こされ、2001 年（平成 13 年) には熊本地方裁判所判決が出ましたが、国は控訴 をせず、原告側の勝訴が確定しました。これを受 けて、同年「ハンセン病療養所入所者等に対する 補償金の支給等に関する法律」が公布、施行され ました。予防法廃止から 5 年後、今から 9 年前の ことで、私たちの記憶に新しいところです。そして、
一昨年 2008 年（平成 20 年）には、全国ハンセン 病療養所入所者協議会を中心とする幅広い運動が 実り、「らい予防法の廃止に関する法律」が廃止さ れ、新たに「ハンセン病問題の解決の促進に関す る法律」が成立し、昨年 4 月から施行されました。 その前文には、「ハンセン病の患者であった者等が、 地域社会から孤立することなく、良好かつ平穏な 生活を営むことができるようにするための基盤整 備は喫緊の課題であり、(中略）また、ハンセン病 の患者であった者等に対する偏見と差別のない社 会の実現に向けて、真摰に取り組んでいかなけれ ばならない。と記されています。百周年を迎えた 丁度その年から、この考え方に沿って新たな歩み を始めることは、大変意義深いことです。

当園開所以来の入所者は、昨年の式典当日現 在で、延べ 9542 名を数え、物故された 4069 柱 の御霊が歴代何人かの園長や三上千代看護婦長 （1957 年にフローレンス・ナイチンゲール記章を 受章）等の遺骨とともに園内の納骨堂に祀られて います。戦時中、一時は子どもを含め 1518 名を 数えた入所者は 291 名となり、平均年齢 81 歳の 高齢社会となりました。

病を得て、それだけでも大変なところに、肉親、

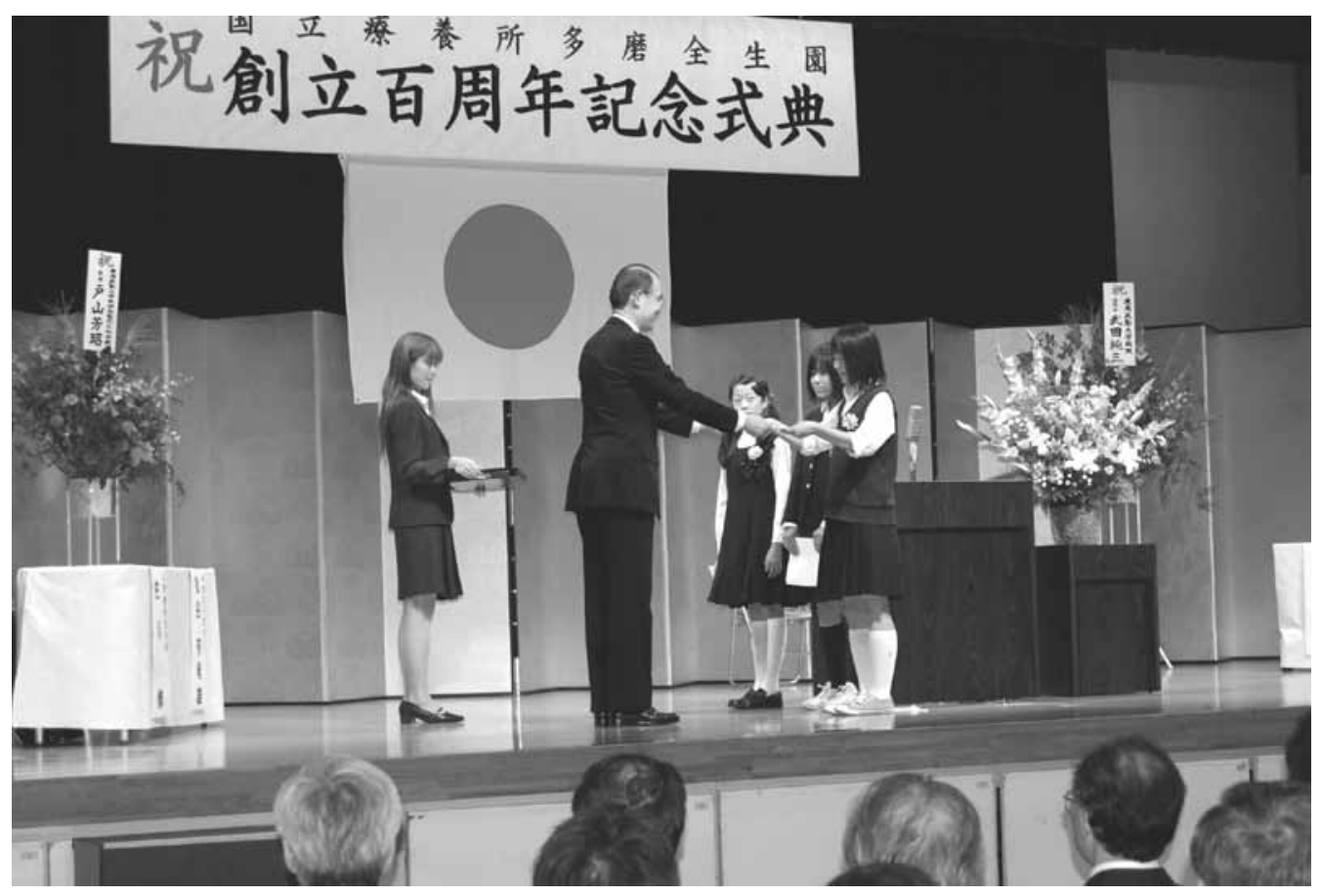


知己と別れ、故郷を離れて入所した人々。社会か ら隔てられ、名前を変え、子どもを持つことを断 念させられ、それこそ骨になっても帰れない日々。 気の遠くなる歳月。戦前に在園した北條民雄の「い のちの初夜」などの諸作品からも伺われるように、 存在を認められないことは、人の尊厳を根こそぎ 奪うものです。私たちは、このことを心の底から 受け止めなければなりません。差別と偏見の重圧 は、想像を絶し、言葉を失わせます。それでも、 この百年、園の内外で人々は生き続けました。園 では、療養と併行して、衣・食・住にわたる喜怒 哀楽を伴う日常の生活が営まれ、加えて、かつて は施設運営に伴う介護、大工仕事、農作業など様々 な園内作業が行われてきました。そして、各種の 文芸、書、絵画、写真、音楽、舞踊、演劇、手芸、 陶芸、園芸 (盆栽、菊作り等) などの文化活動、囲碁、 将棋、カラオケなどの趣味、野球、テニス、ゲー トボールなどのスポーツ、盲人会、老人会、傷痍 軍人会、県人会、文化や趣味の会、自動車などの クラブ活動、演芸会、映画会、音楽会、バス外出 などのレクリエーション活動、また緑化活動、教 育活動、宗教活動、政治活動、自治活動等々、か つては博徒もいたそうですが凡そ人々の暮らしに 伴ういろいろな働きが展開されてきました。慰霊 祭を含む四季の年中行事も、職員や近年は地域の 人たちも多く参加しながら賑やかに行われていま す。文化祭（全生園まつり）などでは作品の展示 が行われ、特に、文芸、記録、評論などは、雑誌 や書籍として当園に限らず多くの作品が出版され ています。百年の歴史を振り返る上での貴重な証 言です。
園は、百年の間ここに生きた人びと及び園に奉 職した人びとの生の証です。入所者が第二の故郷 として緑化に努めた木々を大切にし、御霊の眠る 納骨堂等を守り、後世に残していきたいものです。 これから迎える園の第 2 世紀は、高齢となった入 所者の一人ひとりが心穏やかに療養し、安らかに 生活を全うできるものとなりましょう。そのため にも、旧国立病院など関係の医療機関等との䋖を 強く保ちながら、療養環境の維持向上に努め、職 員一人ひとりがそれぞれの役割を担いつつ、チー ムを組んで入所者の療養と生活の援助に励んでい かなければならないと思っています。

終わりに、かつて当園で少女寮の寮母もされた 故津田せつ子さん（ペンネーム）の短歌 3 首を記 して筆を擱きます。

$$
\begin{aligned}
& \text { 世話せし子一人残らず退園す } \\
& \text { 良き社会人となりて励めよ }
\end{aligned}
$$

たれからも必要とされぬと思ふとき

深き孤独の闇に沈みぬ

$$
\begin{aligned}
\text { 六十四年生かされて来し全生園 } \\
\text { 緑豊かなふるさとなりし }
\end{aligned}
$$

「病みつつあれば」（平成 10 年 けやき出版）より

（本稿は、2009 年 10 月発行の雑誌「多磨」第 90 巻第 10 号に掲載された小生の文を一部改変して寄 稿したものです。) 